\title{
The Role of Contextual Factors in the Influence of ICT on Street-Level Discretion
}

\author{
Peter André Busch \\ University of Agder, Norway \\ peter.a.busch@uia.no
}

\begin{abstract}
Public service workers in the frontline have traditionally enjoyed a wide freedom to make decisions during policy implementation. Research shows that technology has both constraining and enabling effects on public service workers affecting their ability to exercise discretion. What remains unclear is under which circumstances discretion is influenced by technology. Using a case study approach and drawing on neo-institutional theory, this paper studies a court to identify contextual factors affecting the phenomenon. Findings show that technology has no unilateral effect on street-level discretion, and is found moderated by contextual factors such as the degree of social complexity in a case, skills possessed by public service workers, and the need for face-to-face contact. Furthermore, the influence of technology on streetlevel discretion depends on the technology in use.
\end{abstract}

\section{Introduction}

While democratically elected representatives decide on new policies, the actual outcome experienced by citizens in the end comes down to street-level bureaucrats who implement them [1]. The discretionary power of street-level bureaucrats is well established in literature [2]. However, the introduction of information and communications technology (ICT) has been identified to have both constraining and enabling effects on street-level bureaucrats affecting their ability to exercise discretion [3]. Reducing discretion may invoke more standardized processes and erode individualized service. Alternatively, ICT may function as an action resource for street-level bureaucrats and empower them. What is less researched is under which conditions discretion is influenced by technology. Street-level bureaucracies have many similarities but there are also considerable differences. For example, they may vary in regards to inter-agency dependency, degree of centralized structures, or type of work tasks. The purpose of this paper is to identify contextual factors that function as moderators in the influence of ICT on discretion.

Street-level bureaucrats refer to public service workers such as judges, teachers, and social workers who interact directly with citizens and can exercise substantial discretion in their work [1]. Discretion is the freedom street-level bureaucrats have to make decisions concerning individuals regarding the sort, quality and quantity of sanctions, and rewards during policy implementation including the possibility of no sanction at all [1]. E-government is the use of ICT "to design new or to redesign existing information processing and communication practices in order to achieve a better government" [4, p. 237]. Internally, ICT is used to automate, semi-automate, or support work practices. Externally, ICT and the Internet in particular, have been utilized to improve service quality and interactions between government and citizens as well as achieving higher public value ideals such as openness, accountability, and legitimacy [5].

Street-level bureaucrats experience a dilemma. While they are obligated to treat citizens alike, they also need to take individualized concerns into consideration [1]. ICT can influence this tension. Reducing discretion is welcomed from a top-down perspective where discretion often is regarded as an option for street-level bureaucrats to pursue own goals violating public sector values and ideals such as fairness, equality for law, and trust [2]. From a bottomup perspective, discretion is viewed as inevitable to provide personalized service taking social complexity into account, and technology is considered an action resource for street-level bureaucrats [2].

Research concerned with the influence of ICT on street-level discretion is scarce [3] and has mainly focused on social workers. Some studies conclude that ICT is reducing or eliminating street-level discretion, whereas other studies show nuanced effects. Furthermore, studies concerned with contextual factors relate them to rationality pressures such as demands for higher efficiency and effectiveness, where managers are forced to limit discretionary power $[6,7]$. 
The phenomenon is explored through a case study of a Norwegian district court. The judges manage a variety of cases applying a wide range of legal rules. A court is particularly interesting because of its independent position in the constitution common in many countries. The findings from the case study are analyzed by utilizing concepts from neo-institutional theory [8] and discussed by considering identified value positions for e-government [9]. The study is a part of a larger research project aiming at investigating how contextual factors are moderating the influence of ICT on street-level discretion.

\section{Literature review}

Within the information systems discipline, the view of ICT and organizational change has evolved from early deterministic models to models considering social, political, and cultural factors [10].

\subsection{The influence of ICT on street-level discretion}

Negative influence. Studies have found that ICT is influencing discretion negatively through information systems with various degree of automation. Increased routinization caused a reduction in discretionary power where professionals felt their autonomy weakened and decision-making was reduced to tiny adjustments [6, $11,12]$. The persuasiveness of a computer screen is found to be immense and as a result public service workers are afraid of defying it $[13,14]$. Furthermore, technology prevent street-level bureaucrats from manipulating information streams through intermediary positions [15]. Some studies show that professional expertise was impaired when decisionmaking was shifted from professionals to citizens [16] and unqualified staff [17], and these shifts created tensions within the organizations.

Public services such as issuing traffic fines and allocating grants for students can now be done entirely without the assistance of street-level bureaucrats through the use of automated information systems [14, 18]. One study warned about the irreversible effects of decisions made by such systems [13]. While some street-level bureaucracies are able to utilize automated information systems; the findings from these cases cannot be easily transferred to traditional street-level bureaucracies such as courts, police departments, and schools $[3,18]$. Automation is mainly used in streetlevel bureaucracies that handle thousands of cases using schematic legal rules [18].

Nuanced influence. Technology can be used for managerial supervision of formal aspects of work such as the numbers of applications, discrepancies, and complaints. However, ICT makes it difficult for managers to supervise informal aspects, i.e., how discretion is effectively used. This use is highly dependent on the task to be controlled and other contextual factors $[3,19]$. While street-level bureaucrats can alternate between a personalizedflexible and distant-rigid strategy in face-to-face encounters, this is less possible using technology and thus restricts street-level discretion [20]. Additionally, computerized procedures may restrict street-level bureaucrats simply because the number of options is reduced, and could even provide them with an excuse; "the computer says what the computer says" [21, p. 574] thus hiding the discretion effectively used [14]. Furthermore, ICT can provide street-level bureaucrats with much data on their clients and hence make it possible to exert closer control over them [22].

\subsection{Contextual factors}

Specific conditions of street-level bureaucracies affect the influence of technology on discretion. Organizations that process a large amount of cases with many workers performing similar tasks have been found to rely more easily on informatization [18]. Centralized structures experience more pressures to utilize automation than decentralized structures since large-scale organizations can capitalize more easily on economy-of-scale arguments [18]. Also, street-level bureaucracies with efficiency oriented managers are more prone to use ICT for reducing discretion [18, 23]. Rationality pressures make managers prioritize productivity where the discretionary power of streetlevel bureaucrats suffers [6, 7]. Houston [24] argues that rationality objectives emphasize efficiency excessively on behalf of the quality of service delivery.

\section{Neo-institutional theory perspective}

Neo-institutional theory aims at providing explanations of organizational behavior and is appropriate for examining the complex relationships between ICT, organizational characteristics, institutional arrangements, and environmental conditions $[8,25]$. Neo-institutional theory argues that organizational actors do not act solely on the rationalactor models of classical economists but according to social and cultural pressures to conform to current structural forms $[8,26,27]$ sometimes "without any real reflection" [28, p. 176]. Thus, organizational actors do not necessarily seek to maximize efficiency and effectiveness but act because of "irrationalities' arising within the institutional context" [8, p. 369] 
seeking legitimacy more than efficiency. Legitimacy is the "congruence between the social values associated with or implied by [organizational] activities and the norms of acceptable behavior in the larger social system" $[29$, p. 122] with the purpose of becoming "a member-in-good-standing of its class" [30, p. 94, 31]. Legitimacy is considered to be the core concept in neoinstitutional theory [8]. Institutions are not organizations but "social structures that have attained a high degree of resilience" [32, p. 48] with the purpose of producing meaning and stability, i.e., they are values, norms, rules, beliefs, and taken-for-granted assumptions. These institutions can move from place to place and time to time using carriers in which they are embedded. These carriers are symbolic systems (e.g., rules, laws, and values), relational systems (e.g., governance systems and authority systems), routines (e.g., protocols and roles), or artifacts (e.g., objects that comply with standards and possess symbolic value) $[32,33]$.

Institutional effects consider how institutions affect organizations, organizational entities, and other institutions [34]. DiMaggio and Powell [35] introduce the term isomorphism and present three types of institutional pressures: coercive, mimetic, and normative (see Table 1). Isomorphism refer to "a homogeneity of structures observed in several fields" $[8$, p. 370]. Organizations respond to these pressures through various strategies. Oliver [36] proposes five strategic responses exerted through tactics that organizations enact to gain, maintain, or repair their legitimacy (see Table 2).

The influence of ICT on street-level discretion is affected by social, political, and cultural factors [3]. In this study, neo-institutional theory assists in understanding how these factors exert pressures on the judges when they make decisions, and how and why judges respond to these pressures. The judges' central institutions (investigated through public value positions) were identified. The strategic responses judges had to institutional pressures, in the form of competing value positions, were explained by contextual factors and guided by the taken-for-granted institutions among judges.

\section{Research method}

This research was conducted using a case study which is suitable to represent a unique case and when there is a lack of theory [37]. While a case study has limited generalizability, it can shed light on unique situations. An exploratory case study design was selected for the collection of rich descriptive data.
Table 1. Institutional pressures [35]

\begin{tabular}{|l|l|}
\hline $\begin{array}{l}\text { Institutional } \\
\text { pressure }\end{array}$ & Description \\
\hline Coercive & $\begin{array}{l}\text { Formal (standards) and informal (culture) } \\
\text { pressures. Exerted upon an organization by } \\
\text { other organizations in an institutional } \\
\text { environment. } \\
\text { Sources: Dependency, cultural } \\
\text { expectations, and governmental } \\
\text { requirements through law. }\end{array}$ \\
\hline Mimetic & $\begin{array}{l}\text { Imitation of other organizations that are } \\
\text { perceived to be more legitimate encouraged } \\
\text { by uncertainty related to e.g., poorly } \\
\text { understood technologies. } \\
\text { Sources: Consulting firms, industry trade } \\
\text { associations, and employee transfers. }\end{array}$ \\
\hline Normative & $\begin{array}{l}\text { Pressures that stems from } \\
\text { professionalization. Professionals seek to } \\
\text { define their work conditions and ensure } \\
\text { autonomy. } \\
\text { Sources: Inter-organizational networks, } \\
\text { professional associations, and educational } \\
\text { institutions. }\end{array}$ \\
\hline
\end{tabular}

Table 2. Strategic responses to institutional pressures [36]

\begin{tabular}{|c|c|c|}
\hline $\begin{array}{l}\text { Strategic } \\
\text { response }\end{array}$ & Tactic & Description \\
\hline \multirow[t]{3}{*}{ Acquiescence } & Habit & $\begin{array}{l}\text { Following invisible, taken- } \\
\text { for-granted norms }\end{array}$ \\
\hline & Imitate & $\begin{array}{l}\text { Mimicking institutional } \\
\text { models }\end{array}$ \\
\hline & Comply & $\begin{array}{l}\text { Obeying rules and accepting } \\
\text { norms }\end{array}$ \\
\hline \multirow[t]{3}{*}{ Compromise } & Balance & $\begin{array}{l}\text { Balancing the expectations of } \\
\text { multiple constituents }\end{array}$ \\
\hline & Pacify & $\begin{array}{l}\text { Placating and } \\
\text { accommodating institutional } \\
\text { elements }\end{array}$ \\
\hline & Bargain & $\begin{array}{l}\text { Negotiating with institutional } \\
\text { stakeholders }\end{array}$ \\
\hline \multirow[t]{3}{*}{ Avoidance } & Conceal & Disguising nonconformity \\
\hline & Buffer & $\begin{array}{l}\text { Loosening institutional } \\
\text { attachments }\end{array}$ \\
\hline & Escape & $\begin{array}{l}\text { Changing goals, activities, or } \\
\text { domains }\end{array}$ \\
\hline \multirow[t]{3}{*}{ Defiance } & Dismiss & $\begin{array}{l}\text { Ignoring explicit norms and } \\
\text { values }\end{array}$ \\
\hline & Challenge & $\begin{array}{l}\text { Contesting rules and } \\
\text { requirements }\end{array}$ \\
\hline & Attack & $\begin{array}{l}\text { Assaulting the sources of } \\
\text { institutional pressure }\end{array}$ \\
\hline \multirow[t]{3}{*}{ Manipulation } & Co-opt & $\begin{array}{l}\text { Importing influential } \\
\text { constituents }\end{array}$ \\
\hline & Influence & Shaping values and criteria \\
\hline & Control & $\begin{array}{l}\text { Dominating institutional } \\
\text { constituents and processes }\end{array}$ \\
\hline
\end{tabular}




\subsection{Context and case description}

Norway is a constitutional monarchy adhering to the principle of separation of powers prevalent in many countries. The parliament is the legislative branch with the power to issue new legislation. The executive branch is responsible for enforcing legal order and has substantial influence on the legislative process with the opportunity to issue directives. The judicial branch solves disputes based on law and consists of a Supreme Court, appeal courts, and district courts.

The studied district court has more than 15 judges with an average age of approximately 50 years. The court handles more than 7,000 cases every year (including trials). Some of the trials are held with two lay judges. While the administrative staff of the court is under the authority of The National Courts Administration (NCA), each judge is independent. The role of the chief judge is to coordinate the work in the court but he cannot instruct a judge to pronounce a certain verdict in any case.

The judges use several information systems in their work. Lovisa is the main system to handle workflow and information processing needs in the court. The adaptive case management system provides detailed support for complex legal processes, and is used by all district and appeal courts to ensure that legal processes are executed according to law. Law Data and Court Data are two database systems similar to each other with access to collections of online legal resources including laws, verdicts, and scholarly commentaries.

The court was selected as case because of the independent role judges have in the constitution, and a large amount of various cases every year. Judges have traditionally enjoyed a great amount of discretionary power, and they apply a wide variety of legal rules to solve many different cases and inquiries such as weddings, bankruptcies, and serious criminal cases such as child abuse and murder.

\subsection{Qualitative interviews}

A list of judges including the chief judge, "regular" judges, and assistant judges was presented to the researcher for purposeful sampling. Within the second and third group, informants were selected at random. Only one judge held the position as chief judge and he was considered an important informant to obtain a management perspective on the phenomenon. Two judges were assistant judges in qualifying positions whose opinions were deemed important since they are less experienced and were expected to rely more heavily on ICT to find necessary information. In total, seven qualitative interviews of judges were conducted.
All interviews were recorded and lasted, on average, approximately 45 minutes. The interviews were conducted within a period of eight months and by a single researcher ensuring equal conditions during data collection. After transcribing them, the judges were given the opportunity to correct any errors in the transcribed text. The interviews were semi-structured and formulated with open-ended questions to allow informants to speak freely [38]. The informants were asked about topics such as how the court was managed, current information systems and the use of them, and specific conditions influencing the usage.

\subsection{Participant observations}

To gain in-depth knowledge of contextual factors influencing the phenomenon, one researcher engaged in participant observation of three one-day trials in situ. The trials were selected based on the opportunity to participate and held within a period of 14 months. The trials were led by a judge assisted by two lay judges (including the researcher) and dealt with cases of violence and misconduct. Field notes were written down after the trials ended. The field notes focused on how the judge sought information about the cases and the defendants, the general and individual aspects of each case, and how the verdict was decided. No utterances were written down verbatim but instead the essence of the utterances was sought captured.

\subsection{Data analysis}

The data was analyzed to identify unique patterns in the data material [39]. Standard grounded theory techniques were used [40]. The analysis began with revealing the underlying meanings and ideas in the data material using open coding. The coding was based on the language used by the interviewees and the field notes from the participatory observations. Thereafter, axial coding was applied to identify relationships between the codes informed by concepts from institutional theory. A third grounded theory technique, selective coding, is applied to build theory but in this paper contextual factors are reported, which are mainly the results of the axial coding.

\section{Findings}

Findings are organized according to the pressures the court experienced from various groups, contextual factors as moderators of the influence of ICT on discretion, and the expected and emergent effects of ICT. 


\subsection{Demands for quality and efficiency}

The community organizations in the surrounding organizational field are the Parliament, NCA, the district attorney, lawyers, educational institutions, and other district courts. These organizations subject the court to institutional pressures. The institutional pressures promoted two different public value ideals; the efficiency ideal and the service ideal [9]. The efficiency ideal is characterized by visions of cost reduction, and increased productivity and performance [9]. The service ideal is recognized by quality; commitment to public interest, citizen centricity, and service level, which meet the expectations of society [9]. In court, the coercive pressures are found to promote both ideals. Judges contrast the efficiency ideal with the service ideal and this dilemma is similar to the one observed by Lipsky [1] where the work of street-level bureaucrats is characterized by adherence to politically decided policies on the one hand and responsiveness to individual cases on the other hand.

Coercive pressures occur when stated efficiency objectives from the Parliament expect judges to complete cases within a certain period of time. If a deadline is exceeded, a case will be removed from the first assigned judge and reallocated to another judge. This routine is being experienced as slightly stressful: "If the deadline for a case is exceeded, the case will be sent back to the chief judge ... so, this is a slight stress factor". The efficiency of the court is measured regularly and compared to other district courts in the country creating a mimetic pressure on the court since each court "compete" in being most efficient: "Among the large district courts, our court processes cases most efficiently". The chief judge was, as the only informant, positive to an increased use of automation for decision support: "I believe it is positive because it would assist us to quickly get an overview of things that we may have spent a longer time to figure out. I am not sure that all judges think the same way. It may well be that some of the judges would think that this is not good because there is a risk that we would lean too much on the automated system".

ICT provides judges with more information about court practice and much faster compared to 10-20 years ago. Developments in society have created an expectation that this information should increase the quality of court decisions: "You get more information in each case. Through IT, we now have access to more legal sources than we had before when we had to go and look in heavy books. We even lacked access to some of the legal sources that we have access to now. So IT influences us by providing a better basis for making decisions". Judges trust this information and do not necessarily look further for any other relevant information. A judge explains: "Even if it is not necessarily the intention, it may well be the practical outcome because it is a busy workday ... I believe that many judges will make use of systems that can help".

The normative pressure stemming from professionalization is strong because of judges' independent role in the constitution. Judges will not allow the court administrative staff or any other stakeholders to negatively influence the discretionary power that judges hold, unless the constitution itself is altered by the Parliament. The understanding of their role in society is learned and communicated in educational institutions, and upheld in interorganizational networks and professional associations: "Judges are trained in a certain way of thinking". Furthermore, the chief judge emphasizes that judges are expected by the legislator to exercise discretion when making decisions: "A judge has a wide opportunity to exercise discretion. Not only that, we are required to do so". Also, judges are often recruited from other organizations in the organizational field such as law firms and the district attorney's office.

\subsection{Contextual factors}

Judges prioritize high-quality decisions over efficiency claiming that discretion is a necessary prerequisite for quality. They seek to legitimize their existence by referring to contextual factors. In addition, the interaction with technology can create emergent effects influencing how discretion is actually exercised. Table 3 provides an overview of contextual factors that are described in more detail below.

Degree of social complexity. The complexity of human and societal relationships makes it difficult for the legislator to create laws that cover every possible situation that may occur. Due to this, laws and directives are usually formulated in a way that grants discretionary power to judges. The purpose is to avoid unreasonable outcomes. A judge explains the reason for having non-schematic rules: "The legislator would probably have to consider many possible situations ... The legislation had been much more complicated ... It would not fit with real life scenarios because life comes in so many facets ... There would be so many variations and factors that had not been foreseen and one would have risked utterly wrong outcomes in some cases. If you can exercise discretion, then a rule may be adapted and the result will be correct". The degree of complexity varies from case to case. For example, between cases about child protection where the main goal is to achieve a result that is in the best interest of a child, and cases with speeding where the outcome is more or less set beforehand. In the former case, it is 
Table 3. Contextual factors

\begin{tabular}{|l|l|}
\hline Contextual factor & Explanation \\
\hline $\begin{array}{l}\text { Degree of social } \\
\text { complexity }\end{array}$ & $\begin{array}{l}\text { Life comes in many facets making it } \\
\text { impossible to account for all kinds of } \\
\text { possible scenarios. Discretion is } \\
\text { necessary to adapt policies to real life } \\
\text { situations. }\end{array}$ \\
\hline $\begin{array}{l}\text { Societal role of the } \\
\text { public agency }\end{array}$ & $\begin{array}{l}\text { The degree of dependency on another } \\
\text { agencies influence how an agency } \\
\text { considers its "rights". }\end{array}$ \\
\hline $\begin{array}{l}\text { Degree of } \\
\text { professionalization }\end{array}$ & $\begin{array}{l}\text { Stakeholders such as unions guard the } \\
\text { autonomy certain groups of street- } \\
\text { level bureaucrats. }\end{array}$ \\
\hline $\begin{array}{l}\text { Skills possessed } \\
\text { by judges }\end{array}$ & $\begin{array}{l}\text { The degree of computer literacy } \\
\text { among street-level bureaucrats } \\
\text { determines the influence on } \\
\text { discretion. }\end{array}$ \\
\hline $\begin{array}{l}\text { Face-to-face } \\
\text { contact }\end{array}$ & $\begin{array}{l}\text { Face-to-face contact with citizens is } \\
\text { either required or desired for a best } \\
\text { possible understanding of a case and } \\
\text { its outcome. }\end{array}$ \\
\hline $\begin{array}{l}\text { Consequences of } \\
\text { decisions }\end{array}$ & $\begin{array}{l}\text { Decisions with serious consequences } \\
\text { for a citizen should be made by a } \\
\text { human. }\end{array}$ \\
\hline $\begin{array}{l}\text { Technology } \\
\text { features }\end{array}$ & $\begin{array}{l}\text { Specific features of technology have } \\
\text { the potential to affect the influence of } \\
\text { discretion. }\end{array}$ \\
\hline
\end{tabular}

difficult to use automated solutions since it would be difficult for a computer to assess what is in the best interest of a child, even with increasingly more advanced artificial technologies. In the latter case, exceptions from the predefined decisions will only be assessed in a few cases such as speeding to save lives.

Societal role of the public agency. Judges cannot be instructed to make certain decisions since they are independent of other public agencies in the executive branch. One of the judges explains his view on managerial control of his decisions: "The chief judge may well read my decision. But he cannot come to me and say that I should judge in a particular way. It would have been absolutely impermissible". The independent and individual assessment of a case is important for judges and their discretionary power is deemed necessary: "This has simply to do with the rule of law [...]. An individual assessment should be made by a judge. A decision will not be independent and individual if automation is used".

Degree of professionalization. Judges as a group of street-level bureaucrats are highly professionalized with strict qualification criteria and professional associations protecting the integrity and rights of the judges. Due to this, judges tend to conform to norms of conduct and expectations related to work tasks. The high degree of professionalization makes judges very protective of their position in society. They are also concerned with how society assesses judges as a profession: "The courts in Norway enjoy a large degree of trust from society ... compared to courts internationally too". The discretionary power that judges enjoy are important for their integrity. Major efforts are made to ensure that judges are competent to conduct the tasks of the profession: "The process of appointing judges is very thorough".

Skills possessed by public service workers. Judges have a fairly high average age and many of the judges are not as computer literate as the younger judges. The court arranges internal courses on how to utilize ICT. Still, the younger judges believe that they are better able to make use of all the features that the technology in court offers: "I should have liked to see how the older judges go forth when they search 'Law Data' which is a tool adapted for us. There are dozens of useful features but you must be aware of them. And it seems like they spend a lot of time and focus on training without focusing on the right things. For example, if everyone could have a course in how to get the best possible results when searching for verdicts. This is often what you look for". The degree to which ICT is able to provide a judge with more relevant legal sources and thus provide a better basis for the judgment depends on the skills of the judges.

Face-to-face contact. In some cases, face-to-face contact is required. For example, in child protection cases, a judge is expected to explain the decision that is made to a child that asks for such an explanation. One of the judges explains the problems associated with the use of ICT in these cases: "From a psychological perspective, one has stressed that children should meet whoever has made the decision that they should stay with mom or dad and explain why ... this is no easy task for a computer". In other cases, face-to-face contact is not required but still desired. Defendants would like to inform the judge about their specific case and the experience of being listened to is stressed. A judge describes an actual experience: "[The defendant] gave me good feedback because I had listened to him ... I based my decision on what he had said but I still came to the opposite result. It was okay. He had been listened to".

Consequences of decisions. Judges make many decisions every day and the consequences vary. In some criminal cases, the defendant may face many years in prison. The degree to which technology should assist when making decisions with such dramatic consequences, is challenged. One of the judges explains her approach: "The important thing for me is that I make good and right decisions ... That they are as good as possible. That they are as correct as possible ... Efficiency is also important but it cannot be that important that we compromise quality. We must have good quality in what we do". 
Technology features. In addition, the functions and capabilities of the information systems in use were found to influence the phenomenon. ICT is no blackbox and the functions and capabilities of the information systems must also be considered since discretion is likely to be influenced according to the technology in use [41]. For example, templates provided in one of the systems were found to have a habitual effect on the street-level bureaucrats.

\subsection{Expected and emergent effects of ICT}

The judges assessed technology to have no influence on their discretionary power. The chief judge elaborates: "As far as I can see, IT has not in any way limited a judge's ability to exercise discretion ... The judge has a greater opportunity to obtain information with a better basis for his or her decision. But there are no restrictions in the judge's ability to exercise discretion.". While judges expressed this belief, the study showed that institutional pressures are being exerted upon the court that judges are both aware and unaware of and thus affect how the court respond to these pressures.

The normative pressure stems from the judges themselves. The court responds to this pressure through an acquiescence tactic where the court consciously and strategically chooses to comply with this normative pressure. The role of the judge is discussed regularly in local and national forums where judges meet, e.g., in the union organizing judges in Norway: "Almost every judge in the country is a member of the union ... The union discusses various topics to safeguard both our profession and our role in society". The chief judge explains, "there is a dialogue about these things" among chief judges.

Two coercive pressures are exerted upon the court; namely pressures towards higher efficiency and better quality. The analysis shows that judges are not aware of all the effects of these pressures and the court is thus precluded from responding accordingly. According to the taxonomy by Oliver [30], the court responds to these pressures through acquiescence tactics of compliance and habit, and a defiance tactic of dismissal. The main response to the coercive pressures is compliance; judges conform to the routine of using technology to gather more information. Even though more information is collected, technology is so timesaving that it makes them spend less time on each case now compared to 20 years ago, offering more time on complex cases. The efficiency goals of the court are considered legitimate and judges accept such requirements: "It is important to finish a case. We cannot spend like 14 days on every case just because it should be perfected ... so efficiency is important". The judges are clearly concerned with the quality of the decisions they make: "It is okay that efficiency is important. But it cannot be so important that quality is compromised. What we do must be of good quality". Another judge elaborates on the relationship between the efficiency and quality demands: "There is a balance between quality and efficiency. The legislation clearly states the expectations in terms of quality and politicians impose requirements for efficiency. And this is a continuous balance... There is always a new case. At the same time, you should be able to vouch for the decision you have made". While judges comply with demands for efficiency, they do not allow efficiency to compromise quality.

The use of templates is an example on how the judges sometimes follow rules that are taken for granted. One of the judges explains: "The use of templates may reduce discretion ... We base our decisions on the information in the template without exercising too much discretion ... And that is a risk that we must be aware of". Another judge describes her reaction: "Decisions have become much simpler. I had never written a decision as short as the templates. So the first few times I saw them I thought; is this good enough? Then I ... looked at what others had written ... and thought; it is sufficient". The findings show that even though judges use templates to a large degree, there is also an example of a judge that dismissed the template and made necessary time to write a full verdict: "It was a specific decision where I removed the template text and wrote it in full. I thought it was necessary. And then I got a call from one of the lawyers afterwards whom thought it was very good that I had written more than just ... because they observe that the same text is repeated in every case ... So I realized that the dismissal of the template was noticed". The dismissal of the template is an exception to the main rule, which is using the templates by habit.

\section{Discussion}

The findings have shown that judges may be both aware and unaware of the influence of technology on their discretionary power. While judges are not necessarily aware of the emergent effects of ICT, they clearly argue against any reduction in their freedom to make decisions. The arguments are based on contextual factors. Figure 1 exemplifies how a contextual factor (here illustrated by the degree of dependence on other organizations in the institutional field) serves as a categorical moderating variable (the dependence is either low or high).

The discussion of contextual factors can be organized along three lines of arguments; how street- 


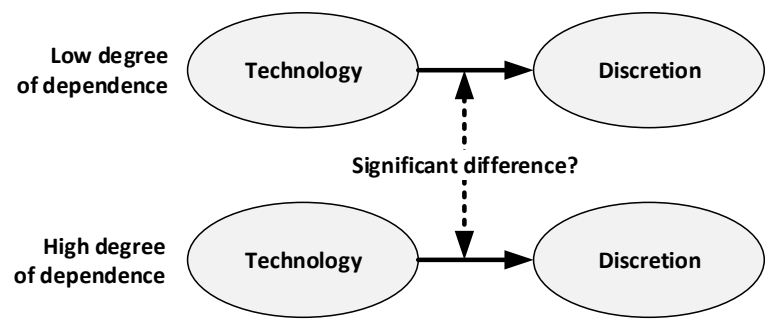

Figure 1. Contextual factor moderating technology and discretion

level bureaucrats prioritize between rival value positions, the nature of service provision, and the interaction with technology. The two former arguments are related to legitimacy since street-level bureaucrats argue for why their discretionary power is needed. The latter argument explains the effects that technology has the ability to create [42].

\subsection{Prioritizing between rival value positions}

Rival value positions are justified or rejected based on contextual factors. For example, the efficiency ideal is considered inappropriate when cases of high social complexity are taken into account. Likewise, the efficiency ideal is favored when considering cases of less social complexity such as speeding.

Judges accept technology as a tool for improving efficiency and quality. When rival value positions are challenged, a survey of Danish local authority managers showed a heavy bias towards efficiency [23]. While the chief judge emphasizes efficiency as important, he states that high quality is expected from society and politicians through law, an aspect also taken into consideration when appointing judges to their office. The identified normative pressure show that judges are protective of their profession and that the quality of a verdict is more important than the time spent to reach a verdict. This can be illustrated by one of the judges who dismissed the template text and wrote a full verdict instead. She was praised by a lawyer for doing this. What would her reaction be if the lawyer had criticized her for using valuable time instead of reaching a verdict quicker? One could easily assume that it would not be as easy to dismiss the template the next time a similar situation had occurred. Considering this particular case, it is easier for independent judges to prioritize the service ideal than for other public agency managers. This is consistent with findings by DiMaggio \& Powell [35] which proposed that "the greater the extent to which an organizational field is dependent upon a single (or several similar) source of support for vital resources, the higher the level of isomorphism" (p. 155).
The degree of professionalization is varying in street-level bureaucracies. Judges demand a high level of autonomy. While public service agencies such as police departments and schools also are characterized by a high degree of professionalization, other agencies such as social service offices have workers with various backgrounds related to education and experience. Professionalization is related to work meaningfulness [2] where reducing discretion or shifting discretionary power to other groups of people are frown upon.

\subsection{The nature of service provision}

The findings seem to imply that the amount of exercised discretionary power is largely a matter of whether politicians want to grant street-level bureaucrats this power or if politicians want decisions based on schematic rules. For example, the criteria for deciding taxes in Norway are purely schematic which allows for automation but at the same time constrain the possibilities for individualized treatment. This may imply that Lipsky's claim stating that "the nature of service provision calls for human judgment that cannot be programmed and for which machines cannot substitute" [1, p. 161] may be questioned based on the value priorities made by politicians. From the perspective of the citizen, the opportunity to present an individual case to a street-level bureaucrat is important because it provides a client with the feeling that they have been listened to. While citizens emphasize the face-to-face contact with government that has been one of the main characteristics of street-level bureaucracy, ongoing discussions debate if the personal contact between client and public service worker should be sacrificed for rationality purposes. This sacrifice has already taken place in several public agencies [18].

Another perspective of service provision is the consequences of decisions that street-level bureaucrats make. This can be illustrated by the work of the judges where penalties can be severe, e.g., life sentence. Automating decisions can be questioned from the rule of law principle where citizens want to be sure that a case has been processed thoroughly and that all necessary aspects have been considered. This perspective is even more important when consequences are serious.

\subsection{Interaction with technology}

The ability street-level bureaucrats have to utilize information systems is a factor moderating how ICT is influencing discretion. Computer literacy in street-level bureaucracies varies to a great extent. Furthermore, 
even those who are experienced with the use of computers may have challenges with utilizing advanced features of technology. The findings indicated that judges could miss out of important information because they were not able to take advantage of all the advanced search features that the database systems provided. This practice could ironically lead to a result where judges that utilized the features of the databases trusted the information provided whereas the other judges had to exercise their discretionary power instead.

In addition, there are variations in terms of what features various technologies offer. When templates were provided, judges tended to use these because they assisted them in a busy work life. Where judges knew about advanced search features, they utilized these to provide them with more information. Several studies have provided evidence of how persuasive computer screens can be implying that street-level bureaucrats, as professionals, can potentially put aside their professional and experience-based judgment and instead choose a solution that the computer suggests. The potential danger of this practice is that it could be institutionalized. Even with more and more advanced technology such as artificial intelligence, one could argue that human judgment is needed because computers only base their decisions on algorithms and not on real life interpretations. While this is the reason for why aircrafts are flown by pilots and humans are driving cars, there is technology available that can do the tasks of humans, e.g., aircrafts are mainly flown by pilots during take-off and landing where the rest of the flight is made by the autopilot.

\section{Concluding remarks}

Analyzing a court and drawing on neo-institutional theory, the influence of ICT on the discretionary power of street-level bureaucrats is investigated and the moderating effect of contextual factors is sought explicated. This study shows that ICT influences the discretionary power of street-level bureaucrats depending on factors related to context here identified as: (1) social complexity, (2) societal role of a public agency, (3) degree of professionalization, (4) computer literacy, (5) the degree to which face-to-face contact is required or desired, and (6) the potential consequences of decisions. Moreover, in this study the utilization of databases was highly dependent on the skills of the street-level bureaucrats. In addition, the information processing software used to organize the workflow contained templates that was found to have a habitual effect on the street-level bureaucrats.
Previous research has mainly focused on the effects of changes in the discretionary power of street-level bureaucrats, and evaluations of these effects. This research contributes to the e-government literature by focusing on the contextual factors that moderate the influence ICT has on street-level discretion, and by considering how functions and capabilities of technology may influence the phenomenon. Furthermore, this study utilizes concepts from neoinstitutional theory which is not known to have been previously applied in this research area.

\section{References}

[1] Lipsky, M., Street-Level Bureaucracy: Dilemmas of the Individual in Public Services, Russell Sage Foundation, 30th anniversary expanded edn, New York (NY), 2010.

[2] Tummers, L., and Bekkers, V., "Policy Implementation, Street-Level Bureaucracy, and the Importance of Discretion", Public Management Review, 16(4), 2014, pp. 527-547.

[3] Buffat, A., "Street-Level Bureaucracy and EGovernment", Public Management Review, 17(1), 2015, pp. 149-161.

[4] Meijer, A., and Bekkers, V., "A Metatheory of EGovernment: Creating Some Order in a Fragmented Research Field", Government Information Quarterly, 32(3), 2015, pp. 237-245.

[5] Bertot, J.C., Jaeger, P.T., and Grimes, J.M., "Using ICTs to Create a Culture of Transparency: E-Government and Social Media as Openness and Anti-Corruption Tools for Societies", Government Information Quarterly, 27(3), 2010, pp. 264-271.

[6] Tummers, L., Bekkers, V., and Steijn, B., "Policy Alienation of Public Professionals: Application in a New Public Management Context", Public Management Review, 11(5), 2009, pp. 685-706.

[7] Peckover, S., White, S., and Hall, C.J., "Making and Managing Electronic Children: E-Assessment in Child Welfare", Information, Communication \& Society, 11(3), 2008, pp. 375-394.

[8] Mignerat, M., and Rivard, S., "Positioning the Institutional Perspective in Information Systems Research", Journal of Information Technology, 24(4), 2009, pp. 369391.

[9] Rose, J., Persson, J.S., Heeager, L.T., and Irani, Z., "Managing e-Government: value positions and relationships", Information Systems Journal, 25(5), 2015, pp. 531-571.

[10] Markus, M.L., and Robey, D., "Information technology and organizational change: causal structure in theory and research", Management Science, 34(5), 1988, pp. 583-598.

[11] Bruhn, A., "Changing Occupational Roles in Audit Society-The Case of Swedish Student Aid Officials", Nordic Journal of Working Life Studies, 5(1), 2015, pp. 3150 . 
[12] Le Dantec, C.A., and Edwards, W.K., "The View from the Trenches: Organization, Power, and Technology at Two Nonprofit Homeless Outreach Centers", 11th ACM Conference on Computer-Supported Cooperative Work, 2008, pp. 589-598.

[13] Keymolen, E., and Broeders, D., "Innocence Lost: Care and Control in Dutch Digital Youth Care", British Journal of Social Work, 43(1), 2011, pp. 41-63.

[14] Wihlborg, E., Larsson, H., and Hedström, K., "“The Computer Says No!" - A Case Study on Automated Decision-making in Public Authorities", 49th Hawaii International Conference on System Sciences (HICSS), 2016, pp. 2903-2912.

[15] Snellen, I., "Electronic Governance: Implications for Citizens, Politicians and Public Servants", International Review of Administrative Sciences, 68(2), 2002, pp. 183198.

[16] Juell-Skielse, G., and Wohed, P., "Design of an Open Social E-Service for Assisted Living", 9th IFIP Electronic Government (EGOV), 2010, pp. 289-300.

[17] Pithouse, A., Broadhurst, K., Hall, C.J., Peckover, S., Wastell, D., and White, S., "Trust, Risk and the (Mis)management of Contingency and Discretion through New Information Technologies in Children's Services", Journal of Social Work, 12(2), 2011, pp. 158-178.

[18] Bovens, M., and Zouridis, S., "From Street-Level to System-Level Bureaucracies: How Information and Communication Technology is Transforming Administrative Discretion and Constitutional Control", Public Administration Review, 62(2), 2002, pp. 174-184.

[19] Jorna, F., and Wagenaar, P., "The 'Iron Cage' Strengthened? Discretion and Digital Discipline", Public Administration, 85(1), 2007, pp. 189-214.

[20] Reddick, C.G., Abdelsalam, H.M., and Elkadi, H., "The Influence of E-Government on Administrative Discretion: The Case of Local Governments in Egypt", Public Administration and Development, 31(5), 2011, pp. 390-407.

[21] Dennis, M.R., "Proletarian or Promethean? Impacts of Automation and Program Integration on Social Service Workers and Their Clients", Journal of Contemporary Ethnography, 35(5), 2006, pp. 552-582.

[22] Hupe, P., and Buffat, A., "A Public Service Gap: Capturing Contexts in a Comparative Approach of StreetLevel Bureaucracy", Public Management Review, 16(4), 2014, pp. 548-569.

[23] Rose, J., Persson, J.S., and Heeager, L.T., "How EGovernment Managers Prioritise Rival Value Positions: the Efficiency Imperative", Information Polity, 20(1), 2015, pp. 35-59.

[24] Houston, S., "Reducing Child Protection Error in Social Work: Towards a Holistic-Rational Perspective", Journal of Social Work Practice, 29(4), 2015, pp. 1-15.

[25] Luna-Reyes, L.F., and Gil-García, J.R., "Using institutional theory and dynamic simulation to understand complex e-Government phenomena", Government Information Quarterly, 28(3), 2011, pp. 329-345.
[26] DiMaggio, P.J., and Powell, W.W., "Introduction", in (DiMaggio, P.J., and Powell, W.W., 'eds.'): The New Institutionalism in Organizational Analysis, 2nd edn., University of Chicago Press, Chicago (IL), 1991, pp. 1-38.

[27] Scott, W.R., "Institutional theory", in (Ritzer, G., 'ed.'): Encyclopedia of Social Theory, SAGE Publications Inc, Thousand Oaks (CA), 2004, pp. 408-414.

[28] Tolbert, P.S., and Zucker, L.G., "The Institutionalization of Institutional Theory", in (Clegg, S.R., Hardy, C., and Nord, W.R., 'eds.'): Handbook of Organization Studies, Sage Publications, Thousand Oaks (CA), 1996, pp. 175-190.

[29] Dowling, J., and Pfeffer, J., "Organizational Legitimacy: Social Values and Organizational Behavior", Pacific Sociological Review, 18(1), 1975, pp. 122-136.

[30] Barley, S.R., and Tolbert, P.S., "Institutionalization and structuration: Studying the links between action and institution", Organization Studies, 18(1), 1997, pp. 93-117.

[31] Meyer, J.W., and Rowan, B., "Institutionalized Organizations: Formal Structure as Myth and Ceremony", The American Journal of Sociology, 83(2), 1977, pp. 340363.

[32] Scott, W.R., Institutions and Organizations, Sage Publications, Thousand Oaks (CA), 2001.

[33] Björck, F., "Institutional theory: A new perspective for research into IS/IT security in organisations", 37th Hawaii International Conference on System Sciences (HICSS), 2004, pp. 1-5.

[34] Jepperson, R.L., "Institutions, Institutional Effects, and Institutionalization", in (Powell, W.W., and DiMaggio, P.J., 'eds.'): The New Institutionalism in Organizational Analysis, University of Chicago Press, Chicago (IL), 1991, pp. 143163.

[35] DiMaggio, P.J., and Powell, W.W., "The Iron Cage Revisited: Institutional Isomorphism and Collective Rationality in Organizational Fields", American Sociological Review, 48(2), 1983, pp. 147-160.

[36] Oliver, C., "Strategic Responses to Institutional Processes", Academy of Management Review, 16(1), 1991, pp. 145-179.

[37] Yin, R.K., Case Study Research: Design and Methods, Sage Publications, 5th edn, Los Angeles (CA), 2014.

[38] Myers, M.D., and Newman, M., "The qualitative interview in IS research: Examining the craft", Information and Organization, 17(1), 2007, pp. 2-26.

[39] Eisenhardt, K.M., "Building Theories from Case Study Research", Academy of Management Review, 14(4), 1989, pp. 532-550.

[40] Strauss, A., and Corbin, J., Basics of Qualitative Research, Sage, Newbury Park (CA), 1990.

[41] Lips, A.M.B., and Schuppan, T., "Editorial: Transforming E-Government Knowledge Through Public Management Research", Public Management Review, 11(6), 2009, pp. 739-749.

[42] Orlikowski, W.J., "Improvising organizational transformation over time: A situated change perspective", Information Systems Research, 7(1), 1996, pp. 63-92. 